\title{
Crypts, Phantoms, and Cultural Trauma: A Hauntological Approach to Recent British First World War Fiction
}

\author{
Anna Branach-Kallas \\ Nicolaus Copernicus University in Toruń \\ kallas@umk.pl \\ Received 12 February 2017; accepted 2 October 2017.
}

\begin{abstract}
In my article, I analyse selected British novels about the First World War published at the turn of the $20^{\text {th }}$ century, from the theoretical perspectives proposed by Maria Torok and Nicolas Abraham in The Shell and the Kernel: Renewals of Psychoanalysis. Pat Barker in Toby's Room (2012) and Sue Gee in Earth and Heaven (2000) imagine their protagonists' difficult evolution from melancholia to mourning after the loss of brothers and/or lovers, at the front. The concepts of incorporation and illness of mourning are used to explore the complicated process of bereavement in Barker's novel, where hauntology becomes a form of honte-ology, from the French honte, shame. In Gee's beautifully melancholic novel, the haunting trauma of loss is subtly evoked by images of empty fields, neglected farms, urban vistas filled with spectral figures of unemployed veterans. Moreover, Earth and Heaven affects the reader so deeply because the understated pain of loss becomes movingly tangible after the accidental death of the central protagonist's six-year-old son, which seems to "condense" the pain of war bereavements a decade after the conflict. My intention is also to demonstrate that Sebastian Faulks in Birdsong (1993), Esther Freud in Summer at Gaglow (1997) and Pat Barker in Another World (1998) approach the Great War as a phantom haunting their contemporary protagonists. The persistence of the unknown past has a profound impact on these characters and only by trying to relate to the Great War do they find answers to their existential dilemmas. This directs our attention to the incomplete processes of First World War mourning, the persistence of endless grief and the potential continuity of unresolved trauma(s) in transgenerational memory. The five novels under consideration also problematise the issue of silence - the unsayable family secret and/or the collective disregard for the national past. The psychoanalytic concept of crypt illuminates the relation between present and past in these fictions and makes it possible to draw
\end{abstract}


a connection with the sociological concept of cultural trauma, referring to certain foundational events constructed as traumatic from the point of view of the British collectivity.

Keywords: hauntology; British First World War fiction; cultural trauma; mourning; commemoration; family memory.

The aim of this article is an analysis of selected British novels of the Great War published during the last quarter of the century-Toby's Room (2012) and Another World (1998) by Pat Barker, Earth and Heaven (2000) by Sue Gee, Summer at Gaglow (1997) by Esther Freud and Birdsong (1993) by Sebastian Faulks - using the hauntologial paradigm proposed by Nicolas Abraham and Maria Torok in The Shell and the Kernel: Renewals of Psychoanalysis (1987; English translation 1994). The four writers approach the Great War as a spectre haunting their protagonists and/or their family lines. Commenting on the memory boom of the late twentieth century, Jay Winter highlights the growing importance of traumatic family memories in our understanding of the past $(2001$, p. 65$) .{ }^{1}$ Winter and other scholars draw the reader's attention to an important recent body of First World War fiction, in which family memories play a central function (see e.g. Renard, 2013, p. 14; Todman, 2008). This "revival" of the theme of the Great War seems today a transnational phenomenon, which signals the desire to move beyond the history of armies and battles, a framework referred to by James Campbell (1999) as combat gnosticism, which for many years has dominated First World War literature and its criticism. Approaching with caution the equation of memory with Shoah (Winter, 2001, pp. 52-53), historians and novelists exploring the 1914-1918 conflict point to its significance as the first holocaust of the twentieth-century and the obliteration of First World War traumas by Second World War memories. This in turn might direct our attention to the incomplete processes of First World War mourning, the persistence of endless grief (Audoin-Rouzeau \& Becker, 2000, p. 17) and the potential continuity of unresolved trauma(s) in transgenerational memory. In the British context in particular, the First World War might be therefore approached as a cultural trauma, a "horrendous event that leaves indelible marks upon" a collectivity's consciousness (Alexander, 2004, p. 1) and re-shapes collective identity as well as collective memory (Eyerman, 2004, p. 60). ${ }^{2}$

\footnotetext{
1 "The memory boom of the late twentieth century is a reflection of a complex matrix of suffering, political activity, claims for entitlement, scientific research, philosophical reflection, and art" (Winter, 2001, p. 65).

2 In contrast to physical or psychological trauma, which shatter an individual's life, cultural trauma refers to a collective wound, "a tear in the social fabric, affecting a group of people that has achieved some degree of cohesion" (Eyerman, 2004, p. 61). The accompanying negative affects reveal that the event is perceived as a threat to the group's identity. An initial reaction of shock is followed by widespread collective mourning and efforts to commemorate the traumatic event (Smelser, 2004b, pp. 266-267). Cultural traumas are discursive constructions - various social actors reinterpret the meaning of the traumatic event, from the vantage point of different affected groups. In this perspective, the First World War as a cultural trauma dwells in the discourses created and contested over time (Smelser, 2004a, p. 37). Literature plays an important role in commemorating such events, as well as in reinterpreting and teaching the younger generations about the traumas of the past.
} 
In Toby's Room (2012), Pat Barker explores the issue of melancholic incorporation. In The Shell and the Kernel: Renewals of Psychoanalysis, Abraham and Torok develop Freud's concept of melancholia, claiming that incorporation occurs when loss is denied, which generates a melancholic fantasy of absorbing the lost other into the self (1994a, pp. 127-130). This causes a profound disorder on the level of self-consciousness. After she learns about the death of her beloved brother Toby, with whom she had an incestuous, sexual relationship, Elinor tries to numb her pain by painting, thus attempting to immortalise her brother in her art. In her case, "incorporation is the refusal to acknowledge the full import of the loss, a loss that, if recognized as such, would effectively transform" her (Abraham \& Torok, 1994a, p. 127). What is more, Elinor's excessive attachment to Toby as an ego ideal and the secret of their incestuous love must be deeply concealed to cover up affects that profoundly unsettle the protagonist (see Abraham \& Torok, 1994a, p. 131). In reference to Elinor, hauntology becomes genuine honte-tology, from the French honte, shame. ${ }^{3}$ Her refusal to mourn results therefore in the formation of what Torok calls a secret tomb inside the melancholic's mental topography, a psychic crypt, in which the object of loss is buried alive (Abraham \& Torok, 1994a, p. 130): “It's almost as if I'm turning into Toby. It's not just me thinking it either, other people have commented. As if you cope with loss by ingesting the dead person..." (Barker, 2013, p. 206; my emphases).

In Toby's Room, bereavement is disordered by Elinor's incestuous desires; she seems to suffer from what Torok has identified as the illness of mourning, which occurs when the death of a beloved person is accompanied by an increase in libido (Torok, 1994a, pp. 113-114). During the visit of her former lover, Elinor initiates sexual intercourse with Paul in Toby's room. From the beginning, the male protagonist experiences a weird sensation of a spectral presence. It is as if the young woman desired to be with him, but at the same time she desired somebody else:

But even in the most passionate moments - and there weren't many—Elinor had seemed to pull away ... Only he'd felt there was something else, a shadow falling across them, cast by something he couldn't see. He'd never known lovemaking like it. It had felt like a battle, not between the two of them - there'd been no antagonism—no, more like he was struggling to pull her out of a pit and sometimes she'd wanted to come with him, and at other times she'd turned back into the dark. (Barker, 2013, p. 107)

Elinor's desire for Toby through Paul's body shows that, as Torok explains, in the illness of mourning, the increase in sexual libido "is a desperate and final attempt at . . . a sudden amorous fulfilment with the object" (1994a, p. 117). Through incorporation, Elinor avoids accepting the loss of her brother, but also the loss of powerful desires that re-emerge at the moment of his death. If, eventually, at the end of the novel, the female protagonist abandons the melancholic crypt and opens up to Paul, a transfer of libido necessary in the evolution of melancholia into mourning (Freud, 1953-1974, p. 244), Barker insists on the

\footnotetext{
${ }^{3}$ This reflection was inspired by my reading of Ranjanna Khanna's "Fabric, skin, honte-ologie."
} 
persistence of Toby's haunting absence in the life of Elinor and her family. Thus, the author seems to suggest that being inhabited by the other - the departed - is a condition of dealing with excessive grief.

In Earth and Heaven (2000), Sue Gee also explores the haunting aspects of post-war grief caused by the loss of brothers and a whole generation of young men. For Walter Cox, the artistically talented protagonist of the novel, who was too young to enlist during the war, the death of his brother John William creates a void, an "emptiness [that] felt like the drop from the edge of a cliff" (Gee, 2000, p. 11). It makes him feel as if he lost half of his body (Gee, 2000, p. 62). For many years after the war his life is devoid of meaning and, like Barker's Elinor, he strives to construct an illusion of sense through art and love. Yet, the memory of the day when the telegram with the fatal news arrived continues to haunt him, his life forever "overshadowed" by the tragedy of war (Gee, 2000, p. 26). Similarly, his friend Euan Harrisson, a sculptor who was old enough to take part in the war, remains inhabited by the ghosts of comrades he lost at Passchendaele. In Gee's beautifully melancholic novel, the haunting trauma of loss is subtly evoked by images of empty fields, neglected farms, urban vistas filled with spectral figures of unemployed veterans. Moreover, Earth and Heaven affects the reader so deeply because the pain of bereavement, so far understated in the novel, becomes movingly tangible after the accidental death of Walter's six-year-old son in 1929. It is as if the heart-rending grief after the loss of the beloved child condensed the pain of war bereavements a decade after the conflict. The war memorial before which the villagers gather every Armistice becomes from now on the locus of the family's and the village's grief (Renard, 2013, p. 311).

While Walter thinks of Geoffrey, and via him of John William, "almost every moment" of his life, half of it spent in mourning (Gee, 2000, p. 292), his little daughter Meredith, born after the war, inherits the burden of traumatic memories. Surrounded by stories of death and an atmosphere of overwhelming grief since early childhood, she is prey to tormenting fantasies of violence and death, which refer to war's fallen heroes, but also function as a premonition of her brother's death (Renard, 2013, p. 241). Moreover, Meredith buries the little boy deep inside her (Gee, 2000, p. 386), succumbing to the fantasy of incorporation, and continues to talk to him every day. Later, she believes the Angel of Death in her father's painting has a malevolent power over her and her family. Consequently, in Gee's novel, the Great War "casts a long shadow" (2000, p. 209) over the generation who survived it but also over the generations that follow, in whom the dead continue to live a half-life. The Second World War, mentioned in parentheses at the end of Earth and Heaven, renders the completion of mourning impossible.

The haunting persistence of Great War memories is thematised by Sebastian Faulks in his Birdsong (1993), which juxtaposes two storylines: the first one is set before and during the First World War and depicts the devastating war experience of Stephen Wraysford and his love-affair with a married woman, whereas the second one, set in the late 1970s, focuses on the efforts of his granddaughter to understand his life. An unhappy thirty-eight year old woman, also involved in a relationship with a married man, Elizabeth Benson is 
not concerned with the First World War and does not know anything about her family's entanglement in the conflict, until she discovers her grandfather's coded journal, in the attic of her mother's house. When she reads an article in the newspaper on the sixtieth anniversary of the Armistice, she feels strangely disturbed: "it seemed to touch an area of disquiet and curiosity that was connected to her own life and its choices" (Faulks, 1994, p. 250). Elizabeth's preoccupation with the past can be interpreted in terms of phantomatic haunting elaborated by Nicolas Abraham, "the unremitting transmission of secrets of one generation to another" (Rand, 1994b, p. 169). Abraham explores the mental topography of excluded realities, people's deeply concealed secrets which are later inherited by their descendants and may disrupt their lives: "The phantom which returns to haunt bears witness to the existence of the dead buried within the other" (1994a, p. 175; italics in the original). The concept of the phantom redraws therefore the boundaries between self and other, past and present, "by suggesting the existence within an individual of a collective psychology comprised of several generations" (Rand, 1994b, p. 166).

In Birdsong, Elizabeth feels a special connection with her grandfather, whose war experience and personal tragedy were never mentioned in her family. Faulks thus problematizes the issue of silence - the unsayable family secret and the collective disregard for the national past - suggesting that "what haunts are not the dead, but the gaps left within us by the secrets of others" (Abraham, 1994a, p. 171). Troubled by the oppressive legacy of silence, Elizabeth researches the past in an effort to reconstruct her grandfather's life, but also to understand the present and herself:

What she described as a mild curiosity crystallized inside her to a set determination. Beginning with the contents of her mother's attic she would track this man down: she would make up for the lateness of her interest in him by bringing all her energy to the task. It would be one way, at least, of understanding more about herself. (Faulks, 1994, p. 250)

Importantly, although apparently Elizabeth is involved in an epistemological quest, Faulks denies any rational meaning to war. When Elizabeth reads about the Great War, she is overwhelmed by her ignorance and is incapable of forging any connection with the events of the past. She therefore decides to visit the battlefields and soldiers' cemeteries in France. Observing the Thiepval Memorial ${ }^{4}$ from afar, she is repulsed by its pretentious grandeur, yet reading on its walls the endless names of the dead soldiers whose bodies were never found, she feels deeply affected. Thus, Elizabeth's investigation leads her to facts, yet most importantly to emotions through which she makes contact with the traumatic past, "not as dispassionate knowledge but as an experience which, although incommunicable, may at least be approximated" (Klonowska, 2014, p. 175).

\footnotetext{
${ }^{4}$ For a detailed analysis of the representation of the Thiepval Memorial in Faulks's Birdsong and Barker's Another World, see Sokołowska-Paryż (2012, pp. 127-185).
} 
Her epistemological quest and acquisition of historical knowledge is necessary to lay the dead to rest, for

Reducing the "phantom" entails reducing the sin attached to someone else's secret and stating it in acceptable terms so as to defy, circumvent, or domesticate the phantom's (and our) resistances, its (and our) refusals, gaining acceptance for a higher degree of "truth." (Abraham, 1994b, p. 189)

Elizabeth's phantomatic connection with her grandfather might have unwittingly influenced her life choices so far, yet when she decides to have a child, she consciously intends to fulfil the promise Stephen gave to his comrade-in-arms, agonising in the tunnel after the explosion. The life of a woman in 1978 might be incompatible with the experience of her grandfather in the Great War but the ontological event of war, due to the powerful descriptions in the novel, as well as the interplay of contrasts and analogies, becomes less aporetic to the contemporary reader.

Esther Freud in her much less famous novel Summer at Gaglow (1997) also uses the theme of a pregnant woman who investigates the family secrets connected with the Great War. The narrative is split between the storyline focusing on Emmanuel, her German ancestor during the First World War, and Sarah's contemporary life in London. The female protagonist, who, like Elizabeth in Birdsong, has a problematic relationship with her partner, is the only person in her family who is haunted by the past and deeply unsettled by how little they know about it. Trying to make sense of it, she can only find some fragmentary stories; her Jewish family, miraculously rescued from the Holocaust, wish to forget about the painful events of the past which led to the loss of their property at Gaglow, in Germany. The pre-Holocaust family past, the First World War in particular, has been silenced and reduced to sordid anecdotes. Freud thus shows how the memories of Shoah have overshadowed those of the First World War; she also renders the unease German immigrants in Britain might feel about their German ancestors' participation in the 1914-1918 conflict. For Sarah, however, the recovery of the past is essential; she treats it as an heirloom vital for her son. At the end of the novel, the enigma is solved, although Sarah is not certain how much of the story was invented and how much is true.

Eventually, like in Birdsong, when the female protagonist makes sense of the phantoms surrounding her, Sarah's life regains order; she reconciles with her lover and together they travel to Gaglow, as, for inexplicable reasons, she feels a connection with the space inhabited by her family before the war. By attempting to understand her ancestors' undisclosed and long-forgotten suffering, Sarah lays the dead to rest and honours her bond with them, which allows her to regain control over her life. It is important to note that in both Birdsong and Summer at Gaglow, the female seeker's pregnant body assures that the past will be transmitted to a younger generation, a promise of redemption (Renard, 2013, p. 324), yet it might also be interpreted as a metonym of phantomatic haunting, the interiorization and retention of another's traumatic memory - the Freudian "foreign body" within (Breuer \& Freud, 2000, p. 6). 
In Another World (1998), Pat Barker offers perhaps the most disturbing vision of the spectral, long-lasting effects of the First World War. The power of the novel lies in Barker's study, "within a single narrative frame, [of] both the haunting effect of successive generations and the troubling relation between the violence of war and violence within the family" (Whitehead, 2004, p. 129). At the centre of the novel is the relationship between the main protagonist, Nick, a middle-aged husband and father, and his grandfather Geordie, a centenarian veteran of the First World War, who, eighty years after the conflict, seems to still suffer from PTSD and re-enacts frontline patrols, crawling through the streets at night with the agility of a young man. It is not as if he were remembering the war, but "actually seeing it" (Barker, 1998, p. 69); in Nick's opinion, Geordie's memories display a "hallucinatory filmic quality" (Barker, 1998, p. 241). Although the old man is diagnosed with cancer, he is convinced that the pain in his side is caused by the wound which he acquired in the war during a bayonet attack, which points to the persistence of the trauma of war, in both his body and mind: "The bleeding bayonet wound's the physical equivalent of the eruption of memory that makes his nights dreadful" (Barker, 1998, p. 227). At the end of the novel, it turns out, however, that the content of Geordie's traumatic memories is not only the cruelty of combat, but the murder of his brother Harry, whom he stabbed to death when he found him agonising in No Man's Land. Geordie is not certain whether it was an act of mercy or an outburst of sibling rivalry, as he was always envious of his brother and, as a child, often wished his death. According to Anne Whitehead, "His fear, which he takes with him to the grave, is that the war gave him the opportunity to act on a murderous impulse toward his elder brother, a 'child's hatred' that otherwise would have existed only in fantasy" (2004, p. 133). After he returned from the front, Geordie has obstinately refused to speak about Harry's death. ${ }^{5}$

Significantly, the trauma of fratricide permeates the novel and creates continuity between generations. In this sense, for his descendants, Geordie's secret traumatic experience becomes "a gap in the unconscious, an unknown, unrecognized knowledge" - the phantom the effect of which "can persist through several generations and determine the fate of an entire family line" (Abraham \& Torok, 1994b, p. 140). In a narrative that resembles a gothic ghost tale, Barker locates phantomatic haunting on both individual and collective levels, addressing the gothic question of family inheritance and the larger question of unresolved social guilt. In Another World, "the family unit, it seems, is constructed on lies and deception, and each generation guards its secrets from those who come before and after" (Whitehead, 2004, p. 138). Nick's complicated family life is governed by violent

\footnotetext{
${ }^{5}$ In Barker's novel, the old man is interviewed late in life by the oral historian Helen, who attempts "to get Geordie to frame his war experience in terms of late-twentieth century preoccupations. Gender. Definitions of masculinity. Homoeroticism" (Barker, 1998, p. 83), which he cannot really understand. He is also skeptical of the public rituals of commemoration as he is well aware of the fact that soldiers were not always motivated to fight for patriotic reasons. He also remembers with resentment how the veterans were abandoned to unemployment and poverty by a government unwilling to consider the devastating mental effects of the war. Helen is not aware of the fact that Geordie's deliberate isolation might have been caused by guilt about his brother's death (see Sokołowska-Paryż, 2012, pp. 170-171).
} 
tensions, which he refuses to acknowledge as he moves into a new house with his partner Fran, who is pregnant with another child, their toddler son Jasper, her eleven-year-old son Gareth, from an earlier marriage, and his own thirteen-year-old daughter Miranda, who must now live with them because her mother has been committed to a psychiatric ward. Jasper's life is constantly jeopardised by the deeply troubled Gareth and Miranda or maybe the ghost of another girl, who used to live in the house. Removing the wallpaper in one of the rooms, Nick's family finds an obscene portrait of the previous inhabitants of the house, the Victorian Fanshawes, whom they recognize as their sinister double (Barker, 1998, p. 41). Nick later discovers that the elder children in the Fanshawe family, Robert and Muriel, were accused of the murder of their younger brother, the offspring of a later marriage, and, although they were never sentenced for the murder, Robert implied their guilt in a letter to his sister, just before he was killed in the Somme offensive. Barker thus questions the stereotype of childhood innocence and seems to suggest that children might act on a motivation to murder. Muriel is the girl who haunts the house and fuses with Miranda, possessing her to assist Gareth when he tries to murder Jasper by throwing stones at him during the family outing at the beach. ${ }^{6}$ Furthermore, the novel resonates with allusions to real-life child murders, such as the Bugler case, Mary Bell's case, and others, thereby highlighting our sense of vulnerability in the social world. ${ }^{7}$

The concept of the phantom, as "a form of communication ... between the unconsciouses [sic!] of two persons" (Torok, 1994b, p. 178), proves particularly useful in the analysis of Another World. As Abraham suggests, although all dead may return, those who are destined to haunt are criminals or social outcasts, "the dead who took unspeakable secrets to the grave" (1994a, p. 175), like Geordie in Another World. In Barker's novel, Nick feels a special connection with Geordie; in fact, he displays emotional indifference or repulsion to other members of his family. During their visit to the war cemetery at Thiepval, Nick seems to absorb the haunting legacy of the war as well as his grandfather's secret, which he never disclosed during his lifetime:

Geordie was attempting to graft his memories on to Nick - that's what the visit was aboutand perhaps, in spite of Nick's resistance, he'd come close to succeeding. Something important happened to Nick at Thiepval and he'd never come to terms with it. (Barker, 1998, p. 74)

According to Abraham, the presence of the phantom in the descendant is the effect of a profound injury of the ancestor (1994a, p. 174). The haunted person reconstructs the secret

\footnotetext{
${ }^{6}$ Whitehead points out that the ghost of the blond-haired girl is ambiguous in the novel and the reader is uncertain whether the apparition is Muriel Fanshawe, the adolescent bully who persecutes Gareth, or Miranda herself (2004, p. 142). Piątek interprets this figure as a symbol of the transgenerational transmission of fratricidal desires (2014, p. 74). Nunn and Biressi also suggest that Muriel's spectral apparitions might be "an unconscious projection of the unspoken anger, aggression, desire, and malevolence that all the family members feel at different times for each other, but refuse to articulate or recognize in themselves" (2005, p. 261). Interestingly, in her analysis of revenants in Barker's novel Whitehead also deciphers the intertextual allusions to Henry James's The Turn of the Screw, thus highlighting the uncertain question of childhood innocence (2004, pp. 140-141).

${ }^{7}$ For a detailed analysis see Whitehead (2004, p. 144) and Nunn and Biressi (2005, pp. 254, 260), who also interpret the violence in the novel through the prism of the class factor (2005, pp. 262-264).
} 
in the form of unconscious knowledge, which manifests itself in uncontrollable behaviour, "showing and hiding that which, in the depths of the unconscious, dwells as the livingdead knowledge of someone else's secret" (Abraham, 1994b, p. 188; italics in the original). Eventually, the phantom seems to dictate Nick's sexual union with Helen, the cultural historian Geordie felt a romantic attachment to; this is suggested by the pervasive scent of Geordie's perfumes which accompanies the sexual act after his death (Barker, 1998, p. 266). In this light, Nick acts as if possessed by his grandfather's phantom; he is not entirely responsible for his own decisions (see Abraham, 1994a, pp. 173-175), "prey to strange and incongruous words or acts, transferred from events ... whose initiator was an other" (Abraham, 1994b, p. 188).

If, at the end of the novel, Nick seems to accept the burden of the past, expressing, at the same time, hope for a new order and cathartic purification - "the past never threatens anything as simple, or avoidable, as repetition" (Barker, 1998, p. 278)—Barker seems to caution the reader about "our need for a past that is neatly packaged and easily resolved" (Whitehead, 2004, p. 134). The eruptions of violence haunt Nick's family as a legacy of their bloodline, with gothic undertones of the sins of the fathers revisiting the sons. In a most unsettling perspective, Barker seems to suggest a connection between Geordie and the most troubled character in the novel - his great-grandson Gareth. The latter belongs to a generation addicted to horror films and violent computer games, which causes him to try to re-enact violence in real life. In Barker's novel, "The cinematic attributes of Geordie's memories are set alongside Gareth's immersion in computer games and movies and his resultant cinematic perception of reality" (Sokołowska-Paryż, 2012, p. 182). Gareth's favourite films and computer games "erode the difference between childhood and adulthood" (Nunn \& Biressi, 2005, p. 262) in a way that echoes the First World War, which, for young men barely out of boyhood, like his great-grandfather who went to war at seventeen, legitimized otherwise inconceivable brutality, disturbing the borderline between reality and childhood fantasies of violence, and thus corrupting their subsequent lives. As Nunn and Biressi point out, "the elision between the past familial murder and the present danger to Jasper fuses public and private trauma" (2005, p. 263) — in this sense, the phantomatic narrative of Another World implicitly suggests the persistence of violence as a legacy of the First World War, which haunts British society as an unresolved cultural trauma that has defined the twentieth century. The complex structure of the novel allows therefore Barker to explore, by means of phantomatic haunting, "the reality of violence as an integral part of human nature, social life and national history” (Sokołowska-Paryż, 2012, p. 166).

In their fictional visions of the Great War, contemporary British novelists examine the impact of the 1914-1918 conflict placing affect at the centre of their narratives. This tendency to exhibit a complex legacy of emotions "has been encouraged by a change in British expressive culture, which it has in turn reinforced, so that the public display of emotion is now not merely accepted but expected" in popular representations of the Great War (Todman, 2008, p. 433). At the same time, this fiction complicates the representation of the past by fathoming complex psychological processes and pathologies of memory and thus highlighting memory's "capacity to serve as a metaphor for a broader movement of 
uncertainty about how to frame the past" (Winter, 2001, p. 65). Although it is debatable whether the First World War remains Britain's "number one national ghost," as Ted Hughes claimed in 1965 (Renard, 2013, p. 13), haunting shapes to a large degree the practices of commemoration in Britain and hauntology proves a useful tool in the analysis of recent British First World War cultural productions. The persistence of melancholia, crypts and phantoms in this fiction exposes hidden social wounds and suggests that the First World War "remains in the collective memory as a persistent traumatic experience that has been insufficiently addressed or acknowledged" (Childs, 2005, p. 62). Barker, Gee, Faulks and Freud thus reinforce the futility myth, as defined by Samuel Hynes (1990, p. 439), which has shaped British representations of the Great War, yet they also expand the traumatizing interpretive framework, bringing their examination of the long-lasting effects of the 1914-1918 conflict closer to post-memory representations of the Second World War. Finally, bridging the present with the past, their fictions examine our most vital concerns today, offering fascinating insight into the enigmas of memory and mourning, private obsessions, the structure of family as well as our social vulnerabilities.

\section{Acknowledgements}

This research was supported by grant DEC-2013/11/B/HS2/02871 from the Polish National Science Centre (Narodowe Centrum Nauki).

\section{References}

Abraham, N. (1994a). Notes on the phantom: A complement to Freud's metapsychology. In N. Abraham \& M. Torok, The shell and the kernel: Renewals of psychoanalysis (pp. 171-176). (N. T Rand., Ed. \& Trans.). Chicago, IL: University of Chicago Press.

Abraham N. (1994b). The phantom of Hamlet or the sixth act, preceded by the intermission of 'truth'. In N. Abraham \& M. Torok, The shell and the kernel: Renewals of psychoanalysis (pp. 187-205). (N. T. Rand., Ed. \& Trans.). Chicago, IL: University of Chicago Press.

Abraham, N., \& Torok, M. (1994a). Mourning or melancholia: Introjection versus incorporation. In N. Abraham and M. Torok, The shell and the kernel: Renewals of psychoanalysis (pp. 125-138). (N. T. Rand., Ed. \& Trans.). Chicago, IL: University of Chicago Press.

Abraham N., \& Torok, M. (1994b). 'The Lost Object—Me': Notes on endocryptic identification. In N. Abraham and M. Torok, The shell and the kernel: Renewals of psychoanalysis (pp. 139-156). (N. T. Rand., Ed. \& Trans.). Chicago, IL: University of Chicago Press.

Alexander, J. C. (2004). Toward a theory of cultural trauma. In J. C. Alexander, R. Eyerman, B. Giesen, N. J. Smelser, \& P. Sztompka (Eds.), Cultural trauma and collective identity (pp. 1-30). Berkeley: University of California Press.

Audoin-Rouzeau, S., \& Becker, A. (2000). 14-18, retrouver la guerre. Paris, France: Gallimard.

Barker, P. (1998). Another world. London, UK: Viking. 
Barker, P. (2013). Toby's room. London, UK: Penguin Books.

Breuer, J., \& Freud, S. (2000). Studies on hysteria. (J. Strachey, Ed. \& Trans.). New York, NY: Basic Books.

Campbell, J. (1999). Combat gnosticism: The ideology of First World War poetry criticism. New Literary History, 30(1), 203-215.

Childs, P. (2005). Contemporary novelists: British fiction since 1970. London, UK: Palgrave Macmillan.

Eyerman, R. (2004). Cultural trauma: Slavery and the formation of African American identity. In J. C. Alexander, R. Eyerman, B. Giesen, N. J. Smelser, \& P. Sztompka (Eds.), Cultural trauma and collective identity (pp. 60-111). Berkeley: University of California Press.

Faulks, S. (1994). Birdsong. London, UK: Vintage Books.

Freud, E. (2009). Summer at Gaglow. London, UK: Bloomsbury.

Freud, S. (1953-1974). Mourning and melancholia. In J. Strachey (Ed. \& Trans.), The standard edition of the complete psychological works of Sigmund Freud, Vol. XIV (pp. 243-258). London, UK: Hogarth Press.

Gee, S. (2000). Earth and heaven. London, UK: Review.

Hynes, S. (1990). A war imagined: The First World War and British culture. London, UK: Bodley Head.

Khanna, R. (2008). Fabric, skin, honte-ologie. In C. Pajaczkowska \& I. Ward (Eds.), Shame and sexuality: Psychoanalysis and visual culture (pp. 159-179). London, UK: Routledge.

Klonowska, B. (2014). Longing for romance: British historical romances 1990-2010. Lublin, Poland: Wydawnictwo KUL.

Nunn, H., \& Biressi, A. (2005). In the shadow of monstrosities: Memory, violence, and childhood in Another World (pp. 254-265). In S. Monteith, M. Jolly, N. Yousaf \& R. Paul (Eds.), Critical perspectives on Pat Barker. Columbia: University of South Carolina Press.

Piątek, B. (2014). History, memory, trauma in contemporary British and Irish fiction. Kraków, Poland: Jagiellonian University Press.

Rand, N. T. (1994a). Introduction: Renewals of psychoanalysis. In N. Abraham \& M. Torok, The shell and the kernel: Renewals of psychoanalysis (pp. 1-22). (N. T. Rand., Ed. \& Trans.). Chicago, IL: University of Chicago Press.

Rand, N. T. (1994b). Editor's note. In N. Abraham \& M. Torok, The shell and the kernel: Renewals of psychoanalysis (pp. 165-169). (N. T. Rand., Ed. \& Trans.). Chicago, IL: University of Chicago Press.

Renard, V. (2013). The Great War and postmodern memory: The First World War in late 20th-century British fiction. Bern, Switzerland: Peter Lang.

Smelser, N. J. (2004a). Psychological trauma and cultural trauma. In J. C. Alexander, R. Eyerman, B. Giesen, N. J. Smelser, \& P. Sztompka (Eds.), Cultural trauma and collective identity (pp. 31-59). Berkeley: University of California Press. 
Smelser, N. J. (2004b). Epilogue: September 11, 2001, as cultural trauma. In J. C. Alexander, R. Eyerman, B. Giesen, N. J. Smelser, \& P. Sztompka (Eds.), Cultural trauma and collective identity (pp. 264-282). Berkeley: University of California Press.

Sokołowska-Paryż, M. (2012). Reimagining the war memorial, reinterpreting the Great War: The formats of British commemorative fiction. Newcastle upon Tyne, UK: Cambridge Scholars Publishing.

Todman, D. (2008). The First World War in contemporary British popular culture. In H. Jones, J. O’Brien, \& C. Schmidt-Supprian (Eds.), Untold war: New perspectives in First World War studies (pp. 417-441). Leiden, the Netherlands: Brill.

Torok, M. (1994a). The illness of mourning and the fantasy of the exquisite corpse. In N. Abraham \& M. Torok, The shell and the kernel: Renewals of psychoanalysis (pp. 107-124). (N. T. Rand., Ed. \& Trans.). Chicago, IL: University of Chicago Press.

Torok, M. (1994b). Story of fear: The symptoms of phobia: The return of the repressed or the return of the phantom? In N. Abraham \& M. Torok, The shell and the kernel: Renewals of psychoanalysis (pp. 177-186). (N. T. Rand., Ed. \& Trans.). Chicago, IL: University of Chicago Press.

Whitehead, A. (2004). The past as revenant: Trauma and haunting in Pat Barker's Another World. Critique, 45(2), 129-146.

Winter, J. (2001). The memory boom in contemporary historical studies. Raritan, 21(1), 52-66. 